\title{
Seasonal variation of the nematode Camallanus anabantis in the fish Anabas testudineus in Loktak Lake, M anipur, India
}

\section{Th R anibala*, M . Shomor endra ${ }^{1}$ and Devashish K ar}

Division of Wetlands, Fishery Science and Aquaculture, Department of Life Sciences, Assam (Central) University, Silchar-11, INDIA

${ }^{1}$ Fish disease Research Lab, Department of Zoology, Thambal Marik College, Oinam-795134 (Manipur), INDIA

*Corresponding author. E-mail: ranithoudam@yahoo.in

Received: J uly 20, 2013; Revised received: September 4, 2013; Accepted: September 16, 2013

\begin{abstract}
The present paper deals with the study of the seasonal variation on the occurrence of the Nematode Camallanus anabantis from the fish host Anabas testudineus from Loktak Lake, Manipur during May 2010- April 2011. A total of 460 number of $A$. testudineus has been sampled for the parasite infection and 335 fishes $(71 \%)$ has been found to be infected with the nematode thereby indicating high prevalence of infection of the nematode parasites in the fish.
\end{abstract}

Keywords: Anabas testudineus,Camallanus anabantis, Loktak lake, Seasonal variation

\section{INTRODUCTION}

Anabas testudineus is one of the common fishes found in Manipur India. It inhabits the majority of lakes, swamps and rice fields etc. They are mostly found naturally and the culture of these has not yet been practiced. It is also one of the most preferred food fish in the state. These fishes are chiefly predatory though wild fish apparently feed on some vegetative matters including algae and rice grains as well as smaller fish, invertebrates and molluscans (Jayaram, 2010). Infection of fish with diverse form of parasite has been known. Among the parasites infecting the fishes nematodes parasites are most common. Fish diseases due to nematode parasite are one of the important problems in fish culture and fish farming Karve (1941), Agarwal (1965) and Soota (1983). The presence of nematode parasite upto a large extent is detrimental for a fish population consequently, imposing big loses to fish farmer. Kar (2007) made detailed study of the limnology and ichthyofauna of the water bodies of north- east (NE) India including diseases in fishes. The present study deals with the prevalence and intensity of infections of the nematode parasite in the fish Anabas tstudineus for a period of 12 months extending from May 2010 to April 2011. The water temperature, one of the significant abiotic variables for seasonal variation has also been taken into account to study the occurrence of the nematode parasites Camallanus anabantis in the fish host Anabas testudineus in Loktak lake, Manipur, India.

\section{MATERIALS AND METHODS}

Fishes of different sizes were routinely collected from
Loktak Lake in Bishnupur district of Manipur. Loktak lake which is the largest natural lake in eastern India is located about $38 \mathrm{~km}$ from Imphal in Manipur state. It has an area of 26000 ha with a catchments area of more than 98000 ha It is situated between $93^{\circ} 46^{\prime} \mathrm{E}-93^{\circ} 55^{\prime} \mathrm{E}$ and $24^{\circ} 25^{\prime} \mathrm{N}$ $24^{\circ} 42^{\prime} \mathrm{N}$. The maximum depth of the lake is $4.58 \mathrm{~m}$ and the average depth is $2.07 \mathrm{~m}$. The unique feature of the Loktak Lake is the floating swamps or mats, locally called Phumdi. Small fishes were killed by pithing and somewhat larger specimens by blow on the top of cranium. The external body surface as well as the internal body e.g. alimentary canal, liver, heart, kidney, gonads, swim bladder etc were thoroughly examined for the occurrence of parasites. The living worms were placed directly in warm $70 \%$ alcohol for fixation. An alternate methods was used for killing and stretching by immersing the worms for 0.5-1 minutes in glacial acetic acid (Bylund et al 1980), and then preserved in $70 \%$ alcohol. Further the worms were cleared in Lactophenol and mounted in glycerine gelly. Data was collected monthwise and the incidence and intensity of parasites was calculated seasonally i.e. summer, autumn, winter and spring.

The data related to percentage of infection, intensity and abundance were determined following the standard formulae of Hoffmann (1999).

\section{RESULTS AND DISCUSSION}

From the recorded data, we have analyzed the incidence of nematode infection Camallanus anabantis in the fish host Anabas testudineus in Loktak Lake, Manipur, seasonally. Table 1 , shows the prevalence, intensity and abundance of infection seasonally. From the 
observations it has been found that the parasite has been recorded from the fish species throughout the year though the incidence of infection is different. There was a high rate of infection during the summer $(88.7 \%)$, medium in autumn (66.8), and spring (42.5\%), and low in winter $(23.2 \%)$. The intensity of infection was highest in summer (2.06), and lowest in winter (1.25). The intensity of infection in autumn and winter was 1.5 each. Chubb (1982) emphasized that water temperature acts directly on the helminthes or indirectly through the host behaviour, especially feeding behaviour and metabolism. In the present study, it may be one of the reasons of leading to higher parasitic infection in the fishes in summer. Leningrad (1999) also pointed out that an increase in temperature to certain limits accelerates the fission and larval development parasites while beyond that limit these processes slow down. In the present study, both the maximum prevalence and intensity of helminth infection were observed in summer. The same has also been reported by Kennedy (1982), Gupta and Singh (1984) and Amin (1986) for more prevalence and intensity of helminthes in summer months in fishes.

\section{Conclusion}

The more prevalence of $C$. anabantis in the fish $A$. testudineus in Loktak lake, Manipur during summer appears to be due to the fact that water temperature acts directly on the larval stage of the nematode parasites or indirectly through the fish behavior, especially feeding behavior and its metabolic activity.

\section{ACKNOWLEDGEMENT}

The authors are indebted to the Director, ZSI, Kolkata, Principal, Thambal Marik College, Oinam for giving laboratory facilities. Thanks are due to Shri S. R. Dey Sarkar of ZSI, for identifying the specimens and to UGC, New Delhi for granting UGC-fellowship to the first author.

\section{REFERENCES}

Agarwal, V. (1965). Some new nematode parasites from freshwater fishes of Lucknow. Indian J. Helminth., 17(1): $1-17$.

Amin, O.M. (1986). Acanthocephala from lake fishes in Wisconsin: host and seasonal distribution of species of genus N eoechinorhynchus Hamann, 1892. J . Parasitol., 72(1): 111118.

Bylund, G., Fagerholm, H.P., Calenius, G., Wikgreen, B.J. and Wikstrom, M. (1980). Parasites of fish in Finland-ii. Methods for studying parasite fauna in fish, Acta Acad. Aboenisis. Ser. B., 40(2):1-23.

Chubb, J.C. (1982). Seasonal occurrence of helminth parasite in fishes. Part-iv. Adult Cestoda, Nematoda and Acanthocephala. Advances in Parasitology. Academic press. London \& New york.20: 1-292.

Gupta, V. and Singh, S.R. (1984). On a new species Pseudocaryophyllaeus ritai sp.nov. (Family 
Caryophyllaeidae) from the intestine of a freshwater fish, Rita rita, from river Gomati at Lucknow, U.P. Indian J . Helminth. 35 (1): 11-14.

Hoffman, G.L. (1999). Parasites of North American Freshwater Fishes. 2nd ed. Ithaca and London, Comstock Publishing Associates (Cornell University Press).

Karve, J.N. (1941). Some parasitic nematodes of fishes-I. J . Univ. Bombay. 10 (3): 9-42.

Kennedy, C.R. (1982). Biotic factors. In: Patterns- their world and ours. Proceedings of the $F$ ifth International Congress of Parasitology. Toronto, Canada. 7-14 August 1982, under the auspices of the World Federation of Parasitologists (Eds Mettrick, D.F and Desser, S.S). Amsterdam. The Netherlands. Elsevier Biomedical Press. pp. 293-302.

Jayaram, K.C. (2010). The Freshwater Fishes of the Indian Region. Narendra Publishing H ouse (Delhi). pp. 616.

Kar D. (2007). Fundamental of Limnology and Aquaculture and Biotechnology. xiv + 609.Daya Publishing House (New Delhi).

Leningrad, E. (1999). Parasites of freshwater fish and the biological control. Israel Program for Scientific translation Ltd. S. Monson Israel. pp: 137-77. 